\title{
The Application Research of Independent Learning Teaching Mode in the Teaching of Physical Education in Military Academy
}

\author{
Yan Chen \\ Academy of Armored Forces Engineering, Beijing, China
}

294244476@qq.com

\begin{abstract}
Keywords: Independent learning; Teaching mode; Physical education in military academy; Application research
\end{abstract}

\begin{abstract}
This paper studies the teaching mode of independent study, detailed analysis of the research status at home and abroad, of autonomous learning, self-regulated learning, teaching mode, teaching mode and the concept of autonomous teaching mode of physical education are analyzed, through the literature, experts interview method, questionnaire survey method, experimental method and mathematical statistics method and logic analysis method to study the application of autonomous learning teaching model in physical education teaching in military academies operability, this teaching mode can not only greatly improve all students lack of ability, at the same time to improve the combat effectiveness of the armed forces and is based on winning future high-tech local wars under conditions of informatization is very important.
\end{abstract}

\section{Introduction}

At present, the general situation of the military training is not high, the highest level is the Navy, followed by the army, armed police, air force last. Therefore, the sports teaching must adopt the reasonable teaching method, cultivate students' sports attitude, interest, based on the development of students, in accordance with the training military high-tech talents as the goal of the training mode, to meet the students of sports psychological needs of students to form the concept of lifelong sports and lay a solid foundation however, autonomous learning is to reflect the training mode, autonomous learning is to adapt to the reform of school education, is an important condition for students to acquire knowledge, and the way of physical development, is the effective way to make up for individual differences. Therefore, it is more important to study the theory and application of autonomous learning in military colleges and universities. The autonomous learning in the military application of vacancy in sports teaching mode, the author thinks that use autonomous teaching mode in sports teaching in military academies, can greatly improve the ability of students lack, to improve the fighting capacity of the army and based on winning local fighting under the condition of modern high technology has very important significance[1,2].

\section{The Concept of Autonomous Learning Teaching Model}

Sports Autonomous Learning. The operation of sports autonomous learning concept is: generally refers to the individual self learning motivation and initiative to create a learning environment, active learning time and method, monitor learning process and evaluate learning results and the above several active process of innovation and ability. If the self-regulated learning can make their own choice and control in seven aspects, the study is fully autonomous, that is to say, if sports learners in learning motivation, learning time, learning environment, learning methods, learning process, learning outcomes and learning a new seven aspects which are able to take the initiative to make a choice control or adjustment, the learning is the self-regulated learning.

Independent Teaching Mode of Physical Education. Autonomous learning is an active, constructive learning process, in this process, students first to determine their own goals, and monitoring, regulation, control objectives, targets and situational characteristics by guide and constrain the cognition, motivation and behavior. In the teaching, and choose the main role of learning methods, the way to emphasize the leading role of teachers and students, pay attention to 
the rational understanding of sports skills and practical ability, actively mobilize students' internal mechanism, a model to make all students to achieve the teaching goal.

\section{Research Methodology}

The research object of this paper is the application of autonomous learning teaching model in physical education teaching in The Academy of Armored Forces Engineering. More than 45 articles, books and teaching materials related to psychology, educational psychology, sports psychology, military education, military training, teaching theory and so on. This paper has collected more than 50 articles about the independent study of physical education, the reform of physical education and the evaluation of physical education in the past ten years by means of inquiry and retrieval of journals, and there are about 6 foreign languages. A comprehensive understanding of the current situation of the research, the latest research results and the forefront of dynamic. It lays the foundation for the thesis, theoretical analysis and demonstration[3,4].

Expert Interviews. For the selection of the research ideas, research methods, experimental measurement index, establish experimental conditions and experimental indexes, the validity and reliability of the methods to visit, telephone, mail or questionnaire of The Academy of Armored Forces Engineering and other parts of the province and the university has rich experience in military theory experts and scholars for consultation and interview listen to their opinions and suggestions.

Questionnaire Survey. Through the consultation of experts, well-known teachers and outside the military sports Professor, one by one operation of the factors determined by experts, after repeated modifications, demonstration, teaching flow diagram of the final form of the recognised experts. Based on the investigation and test of the autonomous learning mode in the experimental class and the control class, 150 questionnaires were issued (the recovery rate was 100\%), and the experimental class and the control class were divided into 75 parts.

After the design of the questionnaire, 25 experts were selected to evaluate the validity of the questionnaire, and the results were shown in table 1. The test results show that the questionnaire has high validity.

Table 1 Validity of questionnaire

\begin{tabular}{|c|c|c|c|}
\hline Score & Number of people & Average score & Total \\
\hline 10 & 1 & & \\
\hline 9.0 & 8 & & 25 \\
\hline 9.5 & 6 & 8.488 & \\
\hline 8.6 & 4 & & \\
\hline 7.9 & 4 & & \\
\hline 7.2 & 1 & & \\
\hline
\end{tabular}

The questionnaire method, namely in the 12 days to recover after the first questionnaire, select 30 survey object were re measured from the sample, then using Pearson productmoment correlation (Pearson) method for reliability analysis, calculation of $\mathrm{R}=0.7872$, in accordance with the statistical requirements, showed that the questionnaire has high credibility.

Experimental Method. The experiment is carried out comprehensive research on two times at the The Academy of Armored Forces Engineering School of a two trainees from October 2014 to December, December 2014 to January 2015, which were randomly divided into two classes for the same level of 75 people per class, by the author as a class teacher, the same qualifications as another class. Before the experiment, the teaching time was four months, and the number of teaching hours was about 96 hours. To ensure the teaching two classes of students basic skills, physical fitness at the same level, enhance the accuracy of the experiment, teaching content, teaching two classes of teaching keep mean, test content, to ensure the reliability of the results.

Mathematical Statistics. The resulting data is processed on the computer using the "SPSS13.0" package.

Logic Analysis. The data are analyzed, summarized, summarized and summed up by the method 
of logic.

\section{Results and Analysis}

Experimental Results and Analysis. The design of the questionnaire issued 150 copies, the recovery rate is $100 \%$, the efficiency is $100 \%$, the content of the survey was aimed at students in sports teaching interest and satisfaction on teaching method, students training mood, increase training enthusiasm and motivation, improve the physical and mental ability and development, is the result of expert batted, approved. It provides reliable basis and reference value for the research process. According to the survey results in statistics, students with interest in sports teaching in $78 \%$, most of the students think that physical education is not too happy, not satisfied with the current teaching methods, teaching methods are traditional and old; generate resentment of training; about $86 \%$ have not heard of their autonomous learning. [5] Do not understand the teaching mode of autonomous learning what exactly is the product of the main class teacher centered, enthusiasm has not fully mobilize the students, because students are a special group of people, when asked the teacher to impart knowledge to our innovative, able to attract students, change the passive training for active training, from teacher centered into with students as the main teaching mode. Therefore, through the investigation results show that the teaching mode of autonomous learning is to carry out reform and innovation into the new concept of teaching in The Academy of Armored Forces Engineering sports teaching, the teaching mode in military colleges will fully give students with autonomous learning training to ensure the full time and space, improve the quality of training. Application of self-regulated learning in PE Teaching in The Academy of Armored Forces Engineering, we carry out scientific training methods and means of teaching and training, the experimental class teaching process teaching, while the control class was the traditional teacher centered teaching mode, after 4 month of teaching training, comparative analysis on the physical quality of the students test, concrete analysis, draw conclusions, as shown in table 2.

Table 2 Comparison of physical quality index

\begin{tabular}{|l|l|l|l|l|l|l|}
\hline Test items & $\begin{array}{l}\text { number of } \\
\text { people }\end{array}$ & $\begin{array}{l}\text { Experimental class } \\
(75) \bar{X}\end{array}$ & $\begin{array}{l}\text { Control class } \\
(75) \bar{X}\end{array}$ & $\mathrm{t}$ & $\mathrm{p}$ \\
\hline $\begin{array}{l}\text { The horizontal bar } \\
\text { pull-up (A) }\end{array}$ & 150 & 9.2 & 9.3 & 0.652 & $>0.05$ \\
\hline $\begin{array}{l}\text { Arm flexion and } \\
\text { extension (A) }\end{array}$ & 150 & 11.0 & 11.0 & 0.535 & $>0.05$ \\
\hline 50 meter run (S) & 150 & $9 " 0$ & $9 " 0$ & 0.378 & $>0.05$ \\
\hline Sit ups (A/min) & 150 & 26.8 & 26.9 & 0.821 & $>0.05$ \\
\hline Push ups (A/min) & 150 & 29.8 & 29.5 & 0.713 & $>0.05$ \\
\hline
\end{tabular}

Two classes before the experiment of horizontal bar pull-up, arm flexion and extension are mentioned in Table 2, $\mathrm{P}>0.05$, no significant difference, compared to homogeneous.

Table 3 Results of the first two classes in the experiment of the 1500 meter run

\begin{tabular}{|c|c|c|c|c|}
\hline group & number of people & $\bar{X}$ & T value & P value \\
\hline Experimental class & 75 & $5^{\prime} 28$ & & \\
\cline { 1 - 3 } Control class & 75 & $55^{\prime} 30$ & 0.72 & $>0.05$ \\
\hline
\end{tabular}

Table 4 Results of the first two classes in the experiment of the 100 meter run

\begin{tabular}{|l|l|l|l|l|}
\hline group & number of people & $\bar{X}$ & T value & P value \\
\hline Experimental class & 75 & $14 " 2$ & \multirow{2}{*}{0} & $>0.05$ \\
\hline Control class & 75 & $14 " 3$ & 0.61 & $>0.05$ \\
\hline
\end{tabular}


Table 5 two classes before the experiment Xuanti performance statistics

\begin{tabular}{|l|l|l|l|l|}
\hline group & number of people & $\bar{X}$ & T value & P value \\
\hline Experimental class & 75 & $67 " 42$ & \multirow{2}{*}{0.79} & $>0.05$ \\
\hline Control class & 75 & $68 " 51$ & 0.79 \\
\hline
\end{tabular}

From table 2, 3, 4, 5 can be seen in the P>0.05, the experimental class and the control class in the basic physical aspects and transfer 6 assessment projects five (100 and 1500 meters run, horizontal bar pull-up, arm flexion and extension, Xuanti,) the test results had no significant difference therefore, the experiment achieved a homogeneous comparison, ensure the experiment has good internal validity. In the course of the experiment, two classes of teaching level, teaching time, teaching times, teaching sites, teaching equipment and other basic conditions.

Experimental Results and Analysis. According to the questionnaire survey statistics: experimental study after a period of time, using the teaching method of autonomous learning, students are significantly increased in military physical training interest and enthusiasm of the happy teaching method of autonomous learning, and the current is very satisfied, the original teacher centered position accounted for $94.6 \%$ down to $27.5 \%$, now teaching with students as the main body, the teacher as the leading new situation. Students exercise independently from the original $28.5 \%$ to the proportion of $85.6 \%$, in the study of the project and the movement of the master has been developed, indicating that the application of independent learning in physical education teaching is feasible.

Table 6 After the experiment, the results of the two classes of the 1500 meter run

\begin{tabular}{|l|l|l|l|l|}
\hline group & number of people & $\bar{X}$ & T value & P value \\
\hline Experimental class & 75 & $5^{\prime} 18$ & \multirow{2}{*}{2.39} & $<0.05$ \\
\cline { 1 - 3 } Control class & 75 & $5^{\prime} 22$ & & \\
\hline
\end{tabular}

As can be seen from table 6, $\mathrm{p}<0.05$, Experimental class and the control class after the test results have significant difference. It shows that the autonomous learning teaching is more advantageous than the traditional teaching to improve the students' 1500 meters and middle distance running endurance.

Table 7 After the experiment, the results of the two classes of the 100 meter run

\begin{tabular}{|l|l|l|l|l|}
\hline group & number of people & $\bar{X}$ & T value & $\mathrm{P}$ value \\
\hline Experimental class & 75 & $12^{\prime \prime} 7$ & \multirow{2}{*}{2.58} & $<0.05$ \\
\hline Control class & 75 & $13 " 7$ & & \\
\hline
\end{tabular}

As can be seen from table $7, \mathrm{p}<0.05$, the experimental class and the control class after the test results have significant difference. That main learning teaching is better than traditional teaching to improve the students' 100 meter race, sensitivity and explosive force of the lower limbs were improved, flying cadets are admitted to our school after college entrance examination, the physical quality is relatively great difference, in the teaching of the targeted teaching, hierarchical teaching, carry out the game, fight the game, relative easy exercise on the quality of a good student, and the pursuit of perfect technology. The quality of the general concentrated intensive training, first from the ideological work, mainly grasp the basic skills practice, let students backbone of the organization of teaching and training, how to create a good atmosphere for training, choose the best venues and equipment to them, allowing them to experience the importance of training, in the test, appropriate to reduce the standard, let them experience the joy of success. The dash to improve 
athletic performance is slow, long time, by comparing the experimental class average increase of 1.5 seconds, the control class increased 0.6 seconds, the experimental class greatly increase, we can see that the new teaching mode is effective and feasible[6].

Table 8 Two classes of horizontal bar pull-up, arm flexion and extension performance statistics after the experiment

\begin{tabular}{|c|c|c|c|c|c|}
\hline Test items & $\begin{array}{l}\text { number of } \\
\text { people }\end{array}$ & $\begin{array}{l}\text { Experimental } \\
\text { class } \bar{X}\end{array}$ & $\begin{array}{l}\text { Control class } \\
\frac{X}{}\end{array}$ & $\begin{array}{l}\mathrm{T} \\
\text { value }\end{array}$ & $\mathrm{P}$ value \\
\hline Horizontal bar pull-up & 75 & 18.6 & 16.7 & 2.268 & \multirow{2}{*}{$<0.05$} \\
\hline $\begin{array}{l}\text { Arm flexion and } \\
\text { extension }\end{array}$ & 75 & 19.3 & 17.6 & 3.316 & \\
\hline
\end{tabular}

As can be seen from table $8, \mathrm{p}<0.05$, the experimental class and the control class after the test results have significant difference. That autonomous learning is better than traditional teaching to improve the students' strength of the upper limb, upper limb strength is an important content of training for pilots, especially in the control of the aircraft during flight, only practice the body, to an invincible position in the future high-tech local war in information. In the teaching and training in the experimental class to inspire and encourage, to reach the standard of excellence students can play basketball, football and other activities, not to be restricted to special remedial teaching to below good students, not the old specialized training, more comprehensive training equipment, ABS plate, push ups, push ups or loading arm push the car, game, inverted contact, so in training, especially in improving student achievement will be great, autonomous learning teaching is conducive to students.

Table 9 Two classes of ladder scores after the experiment

\begin{tabular}{|l|l|l|l|l|}
\hline group & number of people & $\bar{X}$ & T & P \\
\hline Experimental class & 75 & 63.6 & \multirow{2}{*}{2.915} & $>0.05$ \\
\cline { 1 - 3 } Control class & 75 & 63.4 & & \\
\hline
\end{tabular}

Table 9 can be seen in $\mathrm{P}>0.05$, after the experiment, the results of the comparison between the two classes, no significant difference, but the experimental class slightly lower than the control class. This is because the ladder is the need to strengthen the training exercises to improve performance, each school before the vestibular function is poor, is "O", sometimes by self training is not up to the strength level, the teachers must strengthen the training system, Xuanti practice it is mainly for centrifugal motion around a horizontal axis and rotation. Mainly to improve the spatial orientation ability of flight cadets and antidizziness ability, many factors affect the performance, especially the factors of technical quality factor and psychological training level. The ladder is specialized gymnastics equipment, iron structure, training more dangerous, it is prone to accidents, some students do not dare to action, not on speed, therefore training to strengthen the protection and help to prevent accidents. As a result, teachers can not give students too much room for independent training and learning, which is one of the important factors.

\section{Conclusion}

Through the initiation of autonomous learning and teaching training, students are better able to master the technical movements, so that the physical quality of students, training level, exercise ability has been greatly improved and gradually develop a sense of lifelong sports. The inspection found by contrast the development of autonomous learning teaching and training is more conducive to students' autonomous learning teaching experiment fully embodies students subject 
consciousness and unique, to meet the needs of students' personality development, from the original faculty dominant change into students main body. Through independent learning teaching can effectively stimulate students' interest in sports, to eliminate the psychological homesick students, to let me practice change as I want to practice a good atmosphere and training atmosphere.

\section{References}

[1] B.Hu. New requirements of new curriculum for teachers. Planning, teaching materials and teaching methods,2004.(In Chinese)

[2] L.M. Zhang. Research on the practice of "three independent" physical education in Colleges and universities. Journal of Beijing Sport University.2005.8,28(8).(In Chinese)

[3] X.Lin. An empirical study on Autonomous Learning in College Physical Education. Journal of Southeast University.2006.7,21(4).(In Chinese)

[4] Y.H. Wang. A study on the cultivation of students' autonomous learning ability in Physical Education. Journal of Anhui Sports Science,2006.10.(In Chinese)

[5] Dyson, B.,and Grineski, S, Using cooperative learning structures to achieve quality physical education Journal of Physical Education, Recreation and Dance 2001.

[6] Jimmy H.Is he. Cooperative Learning in all Elementary Physical Education Program Joumal of Physical Education, Recreation and Dance 2002. 